$$
\begin{aligned}
& 5537 \\
& .027
\end{aligned}
$$




\section{S 537}

.027

Copy 1
THE

OHIO STATE UNIVERSITY BULLETIN

\section{VIEW S}

OF THE

\title{
College of Agriculture
}

\author{
$3 \cup \mathrm{N} B .1911$
}

Published by the Univendty at Columburs

Entered as second clase mafter November 17, 1906 at the

Post Office at Colnmbus, Ohlo, under Act of Condress, July 16, 1894 . 


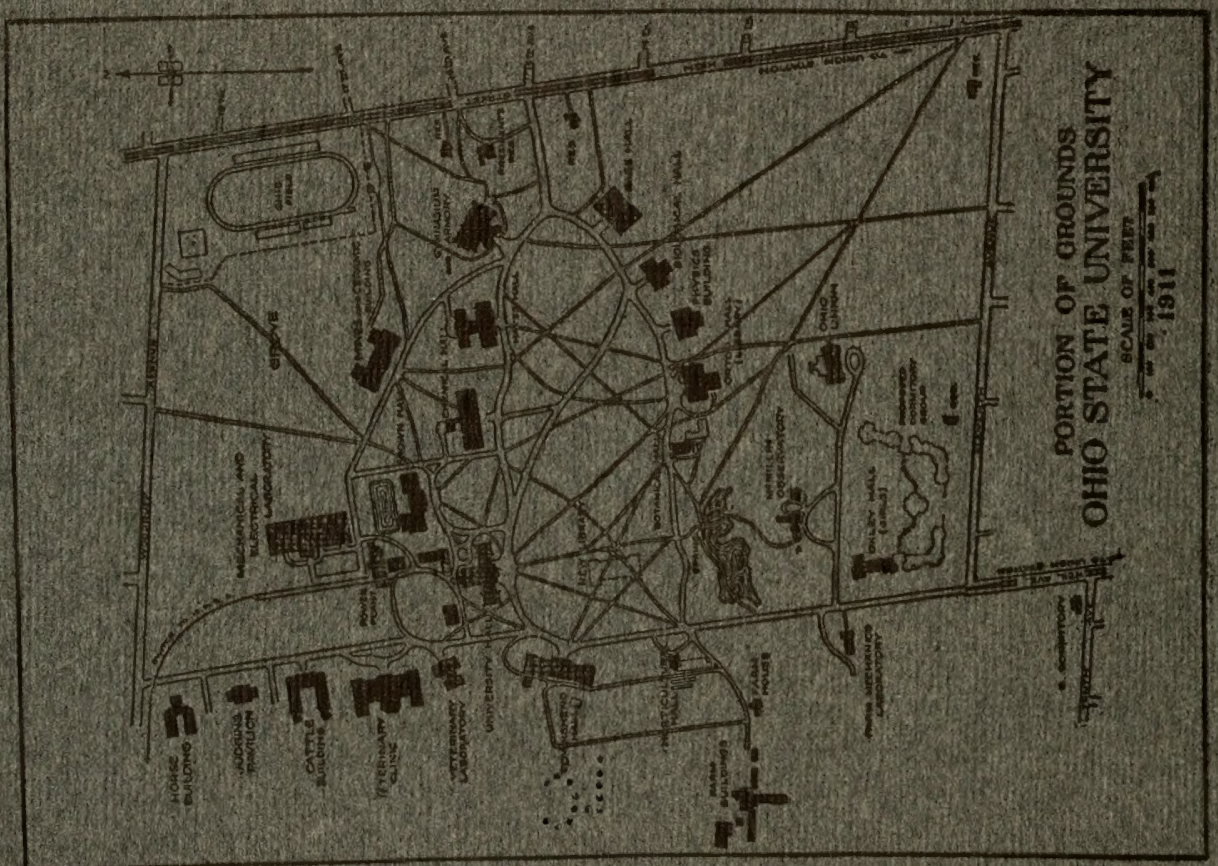




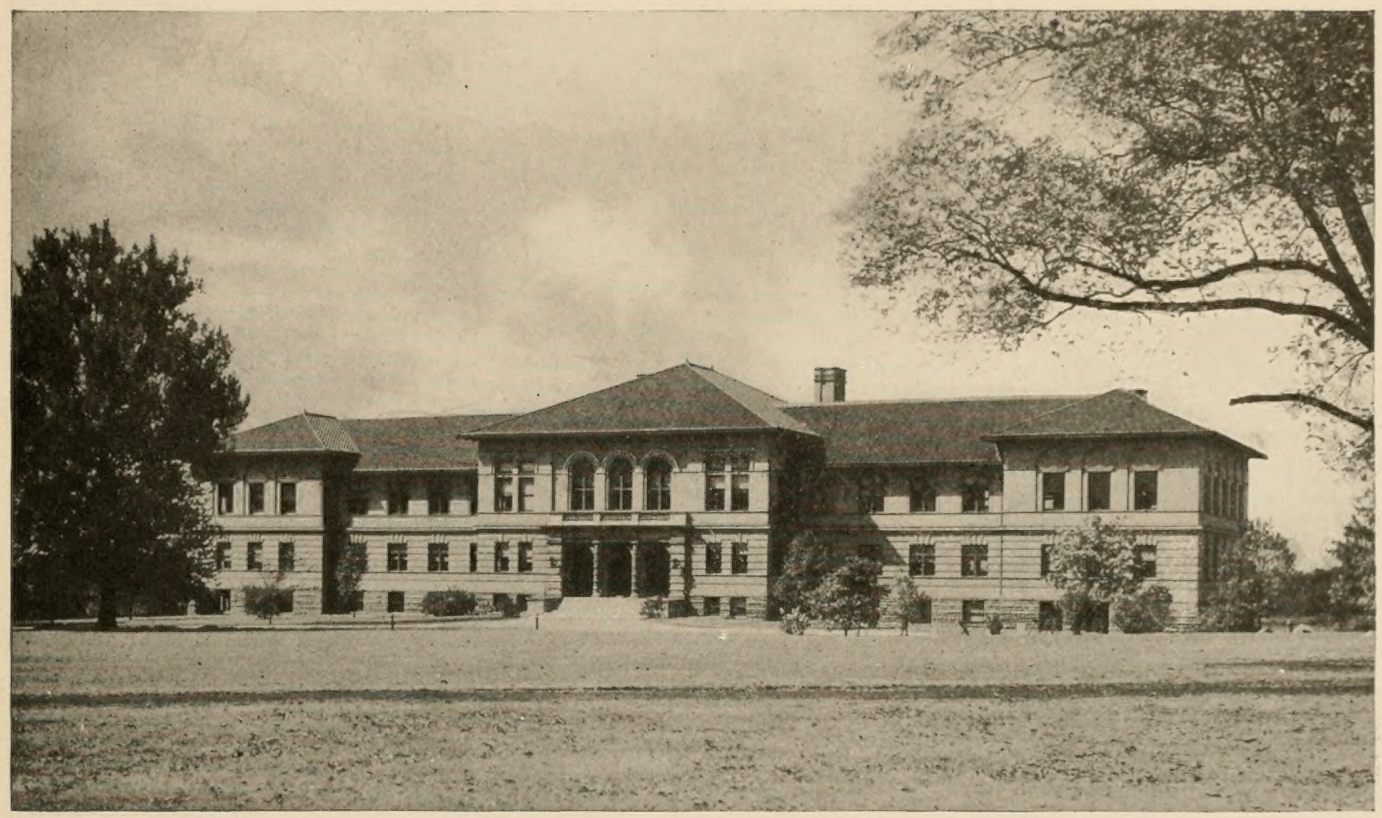

TOWNSHEND HALL

DEPARTMENTS OF AGRICULTURAL CHEMISTRY, AGRONOMY, DAIRYING, AND RURAL ECONOMICS 


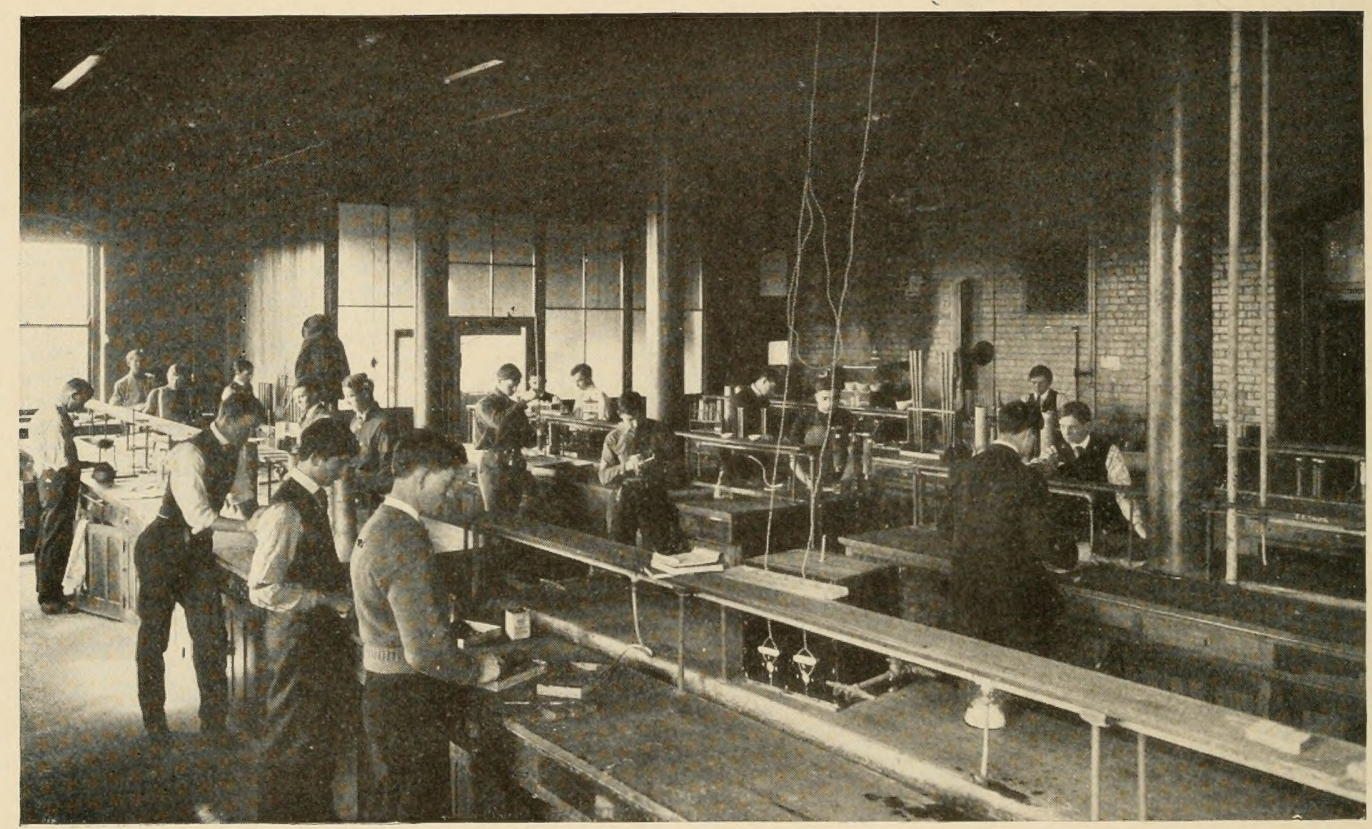

SOIL PHYSICS LABORATORY 


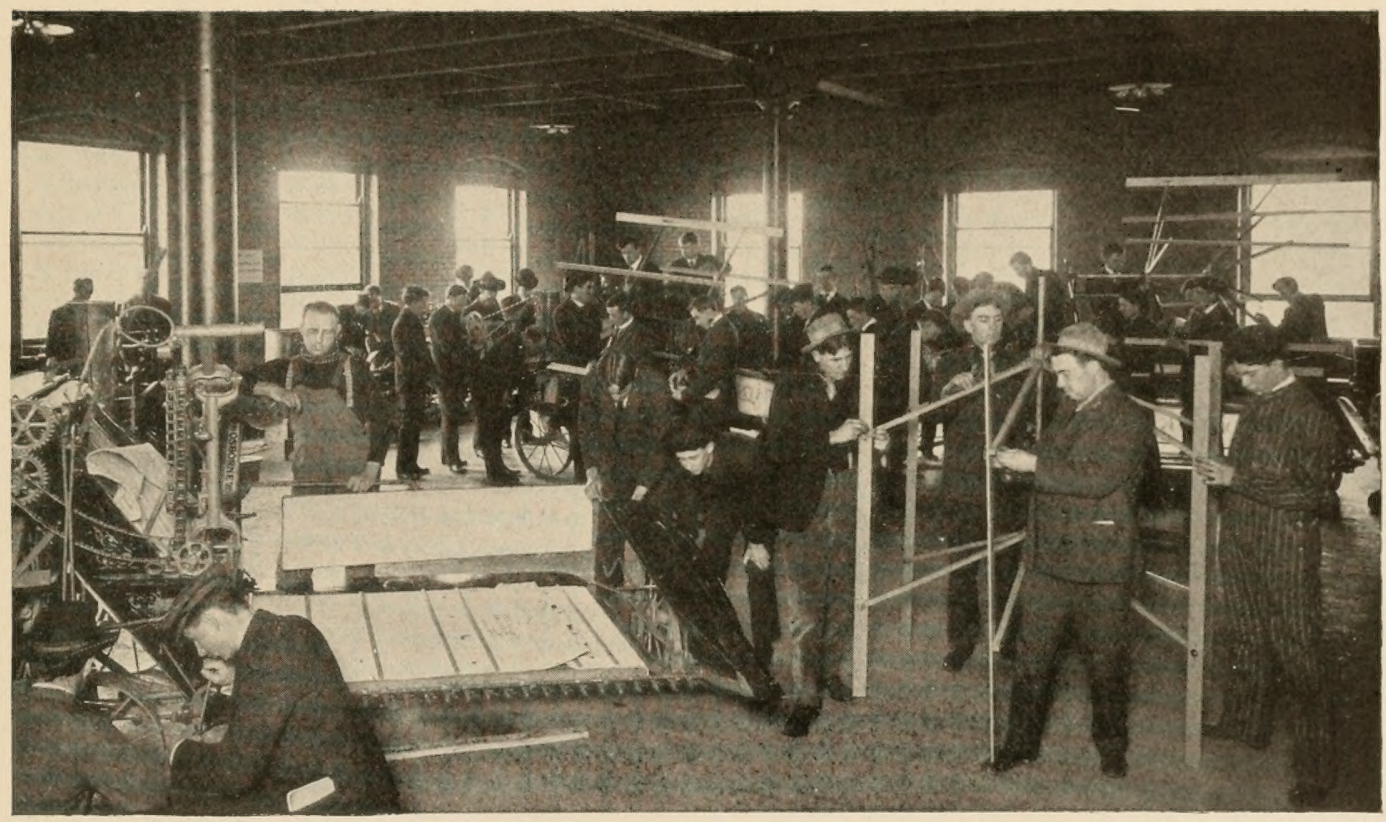

FARM MACHINERY LABORATORY 


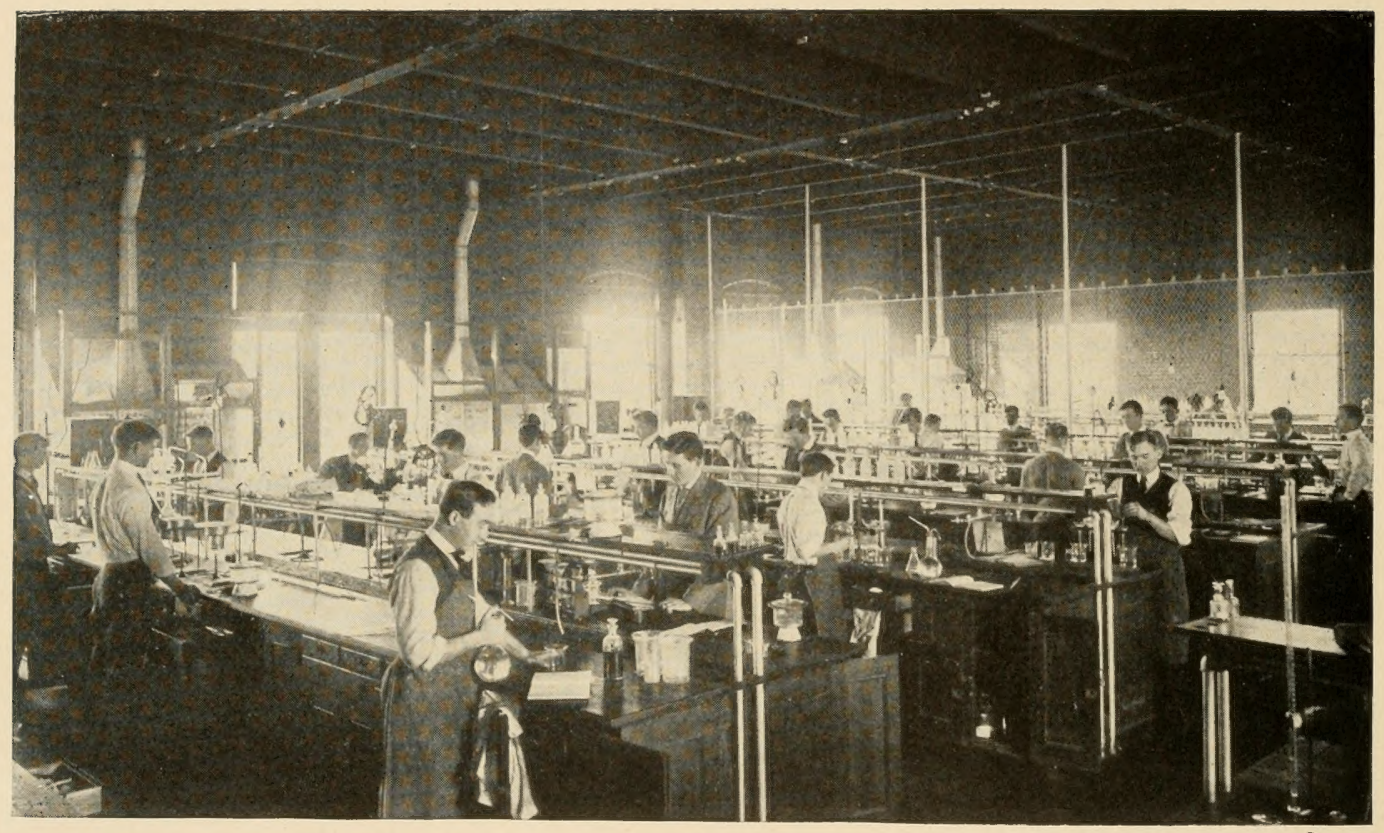

AGRICULTURAL CHFMISTRY LABORATORY 


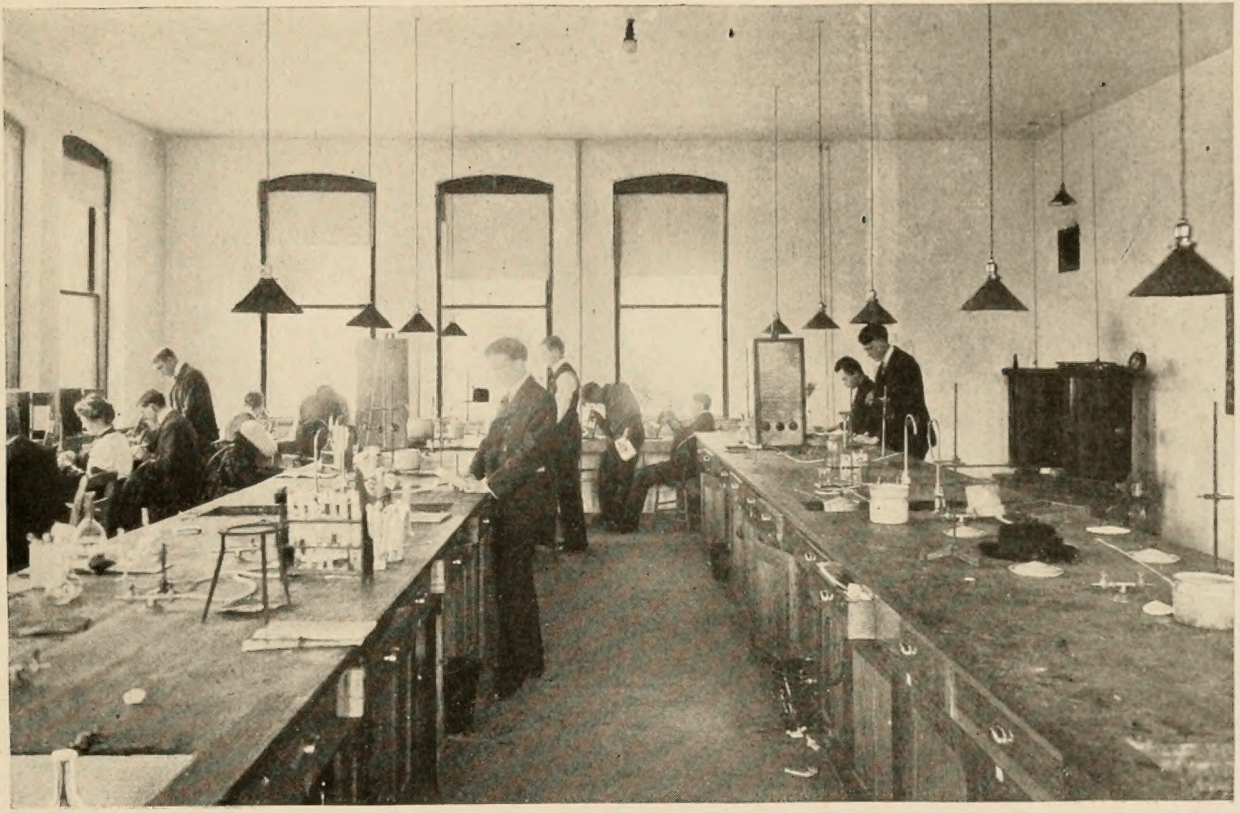

BACTERIOLOGY LABORATORY 


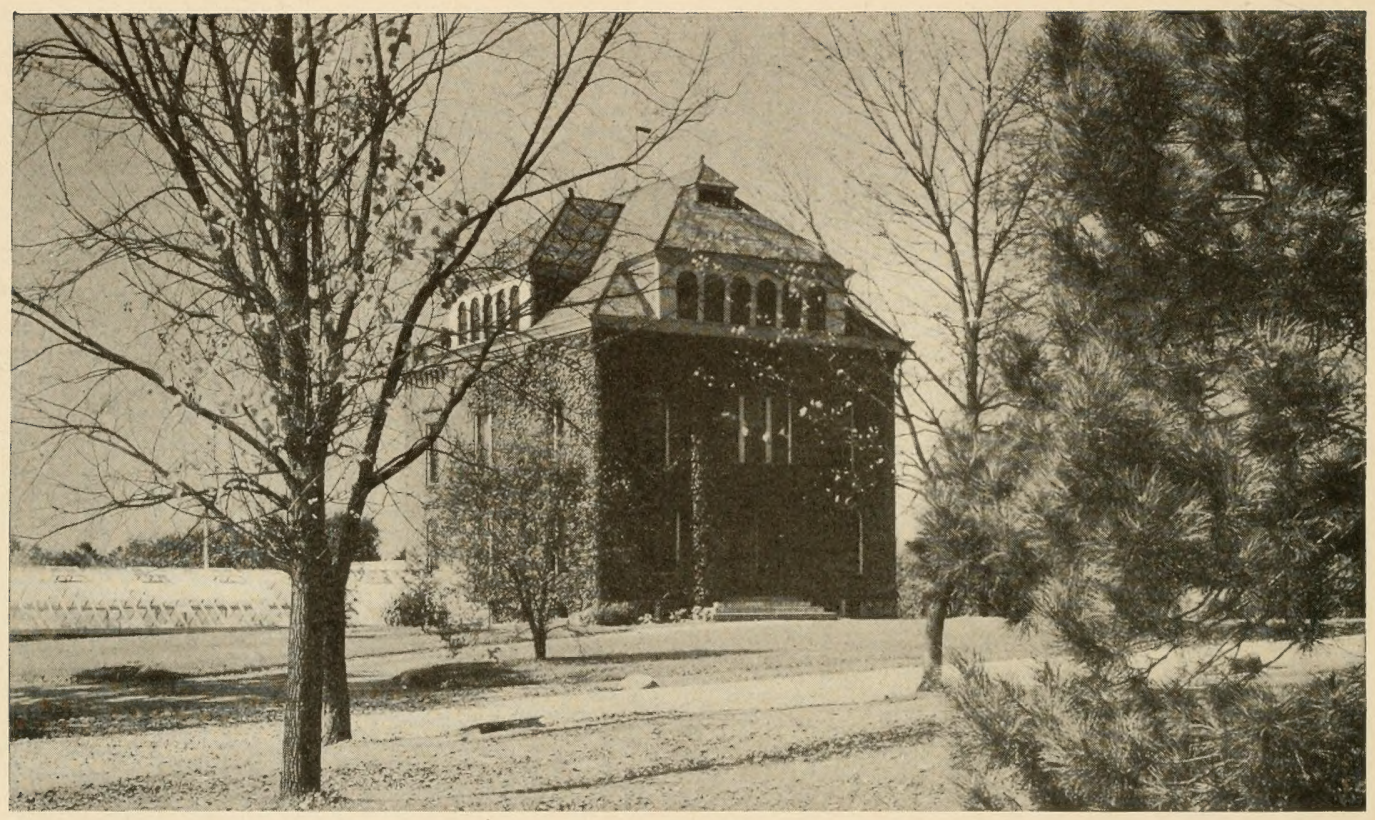

HORTICULTURAL HALL

DEPARTMENTS OF HORTICULTURE AND FORESTRY 


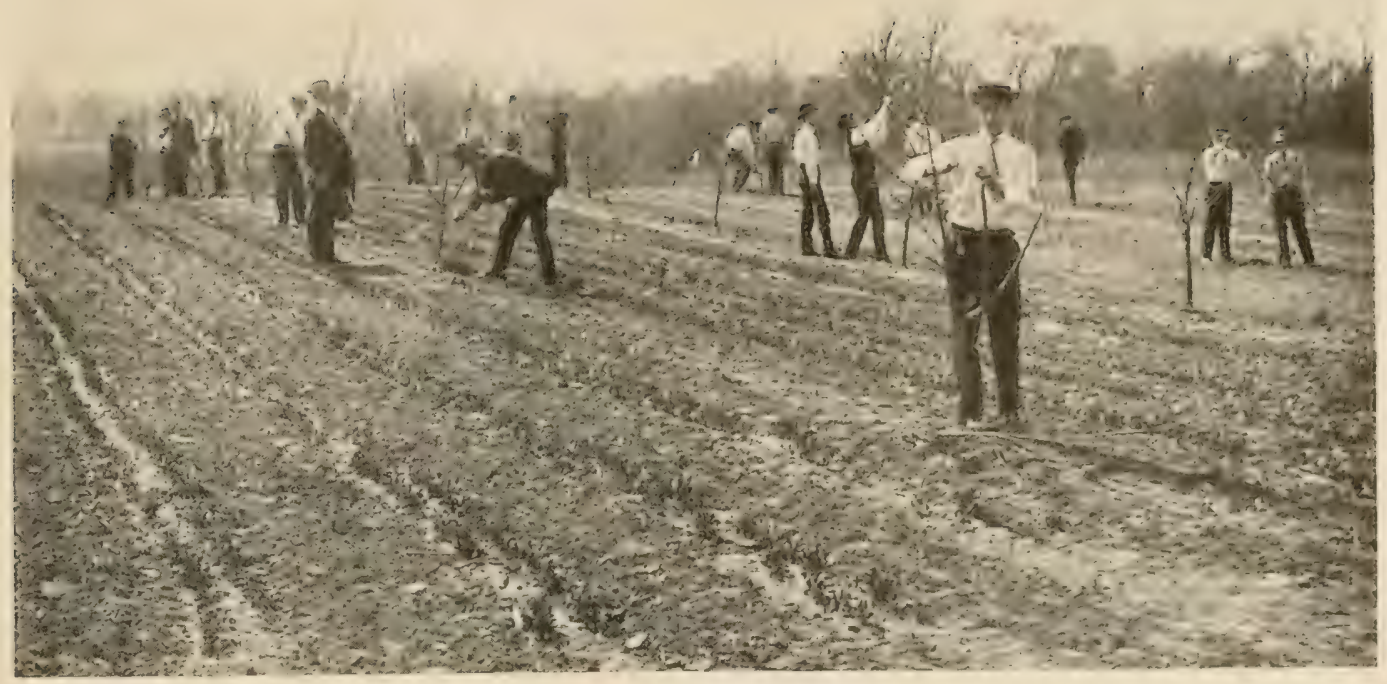

PRUNING-A CLASS IN HOPTICULTURE 


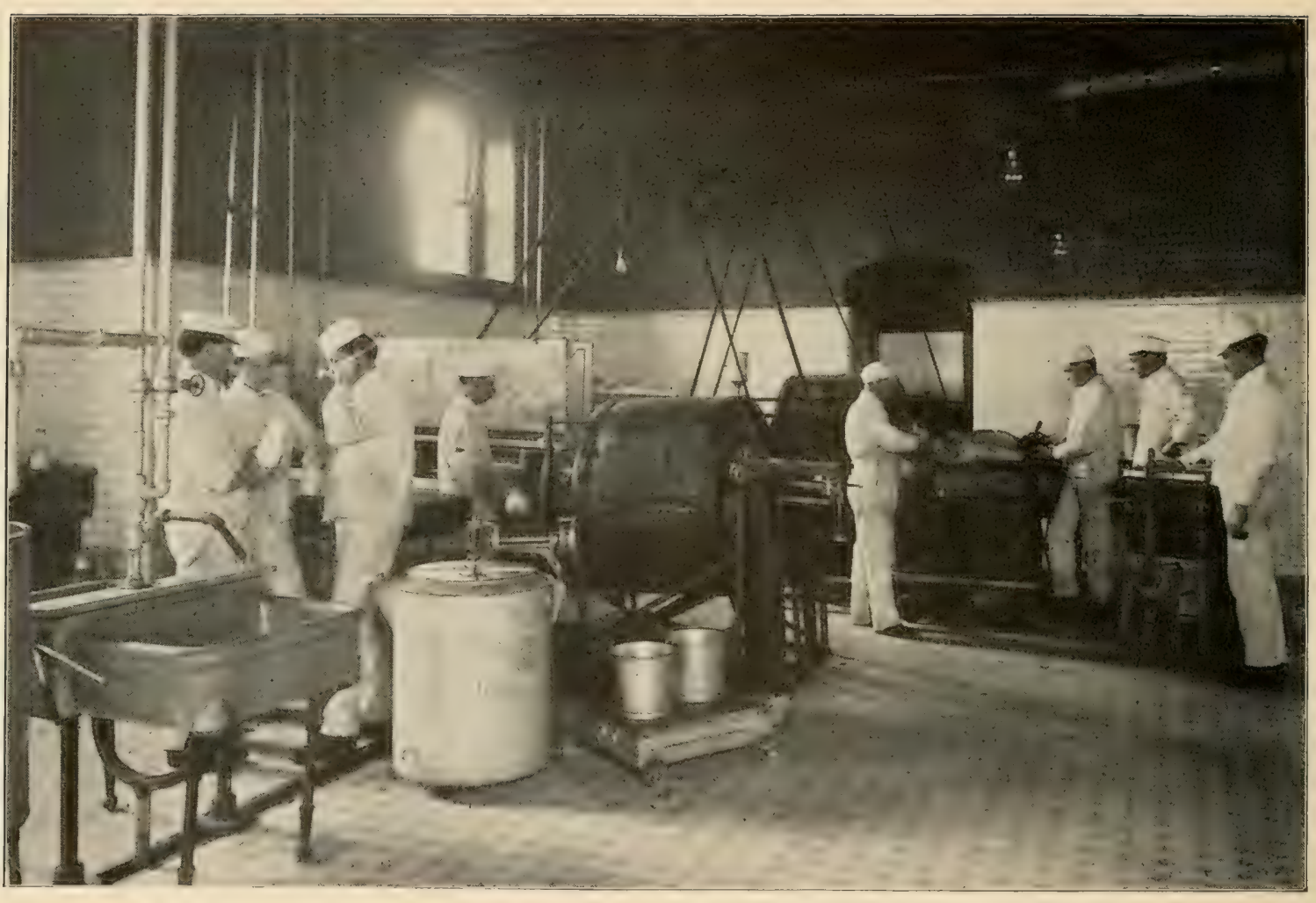

A DAIRY IJABORATORY 


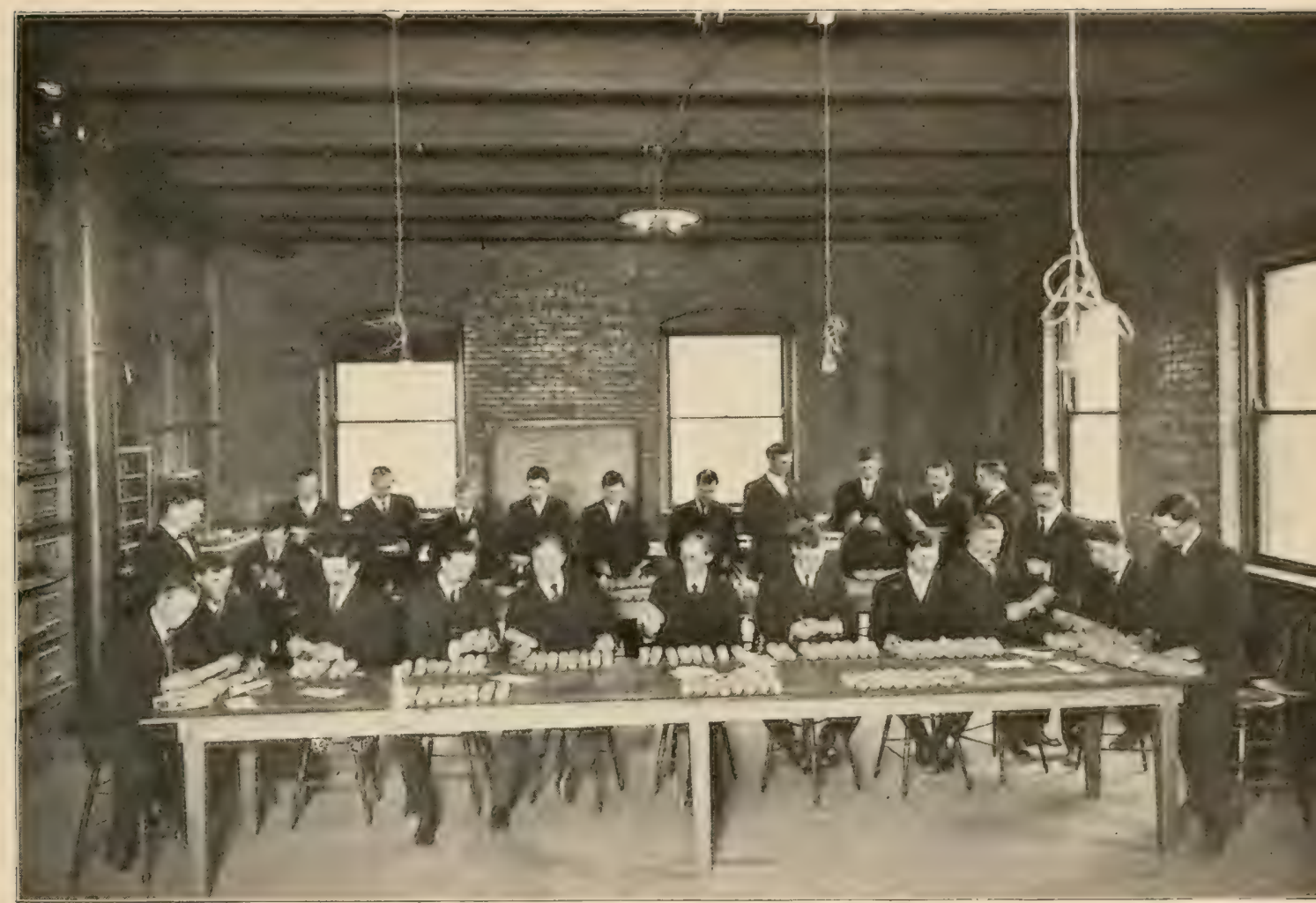

A CORN .TUDGING CIJASE 


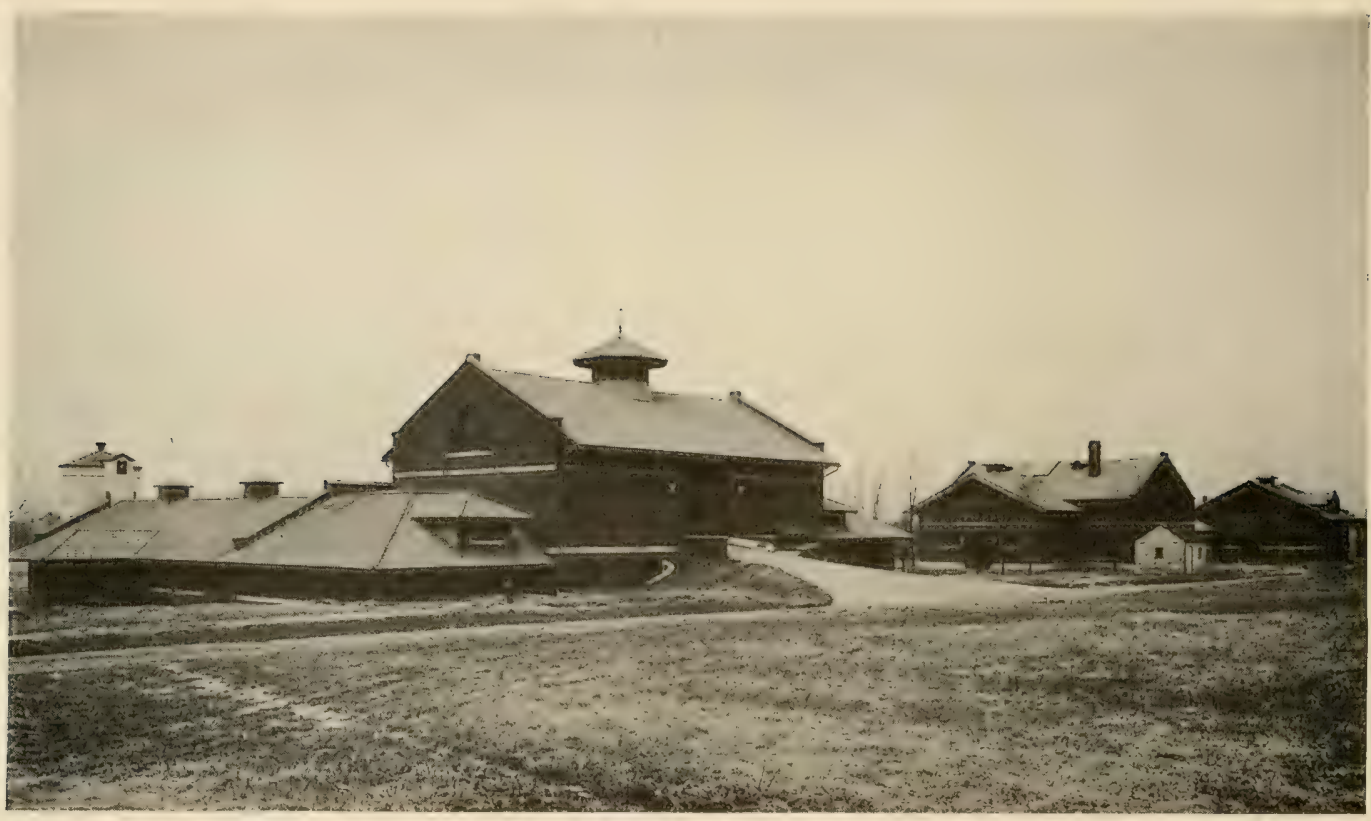

CATTLE BARN

JUDGING PAVILION

HORSE BARN

THE BARNS

DEPARTMENT OF ANIMAL HUSBANDRY 


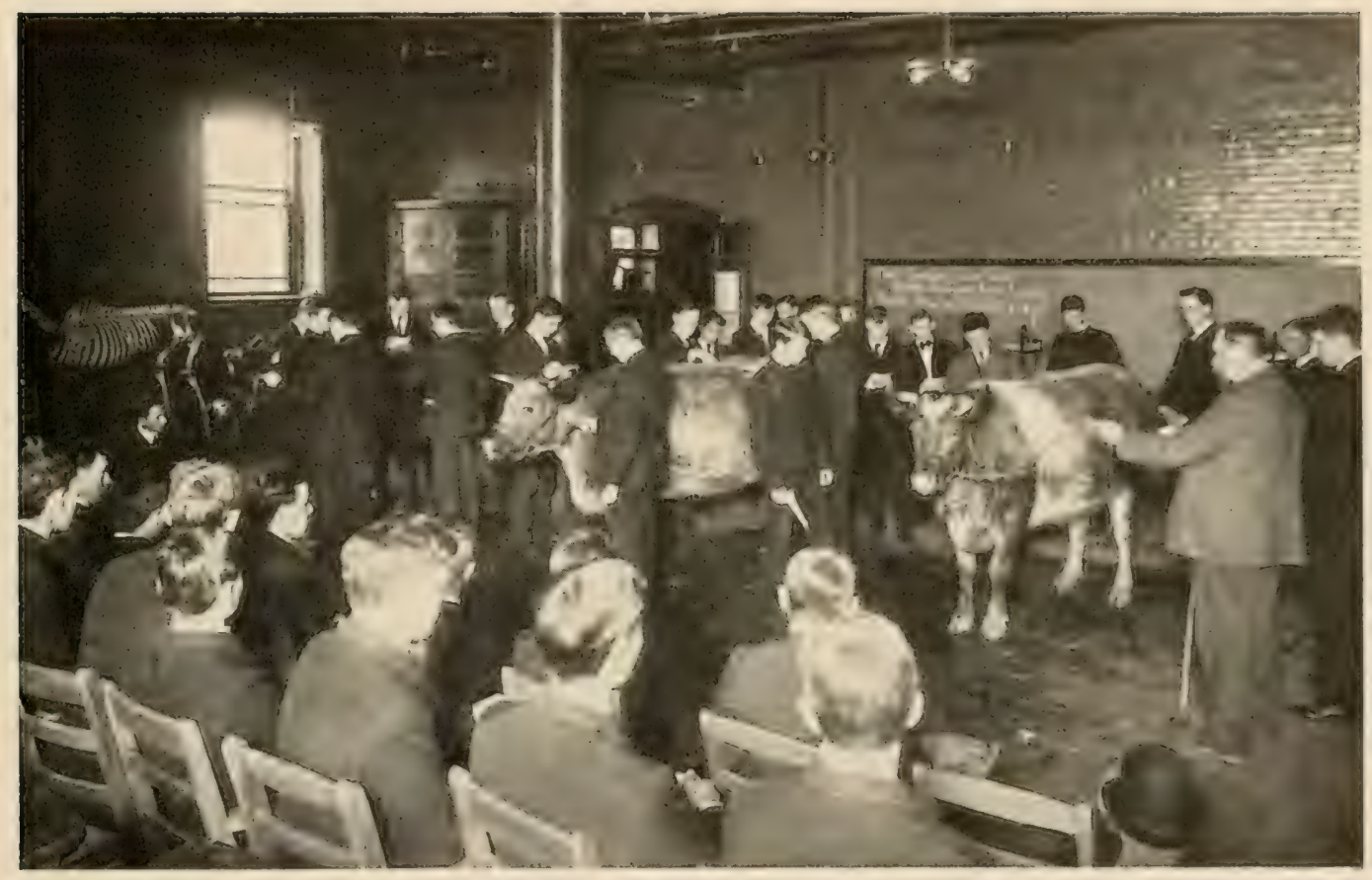

A CLASS IN STOCK JUDGING 


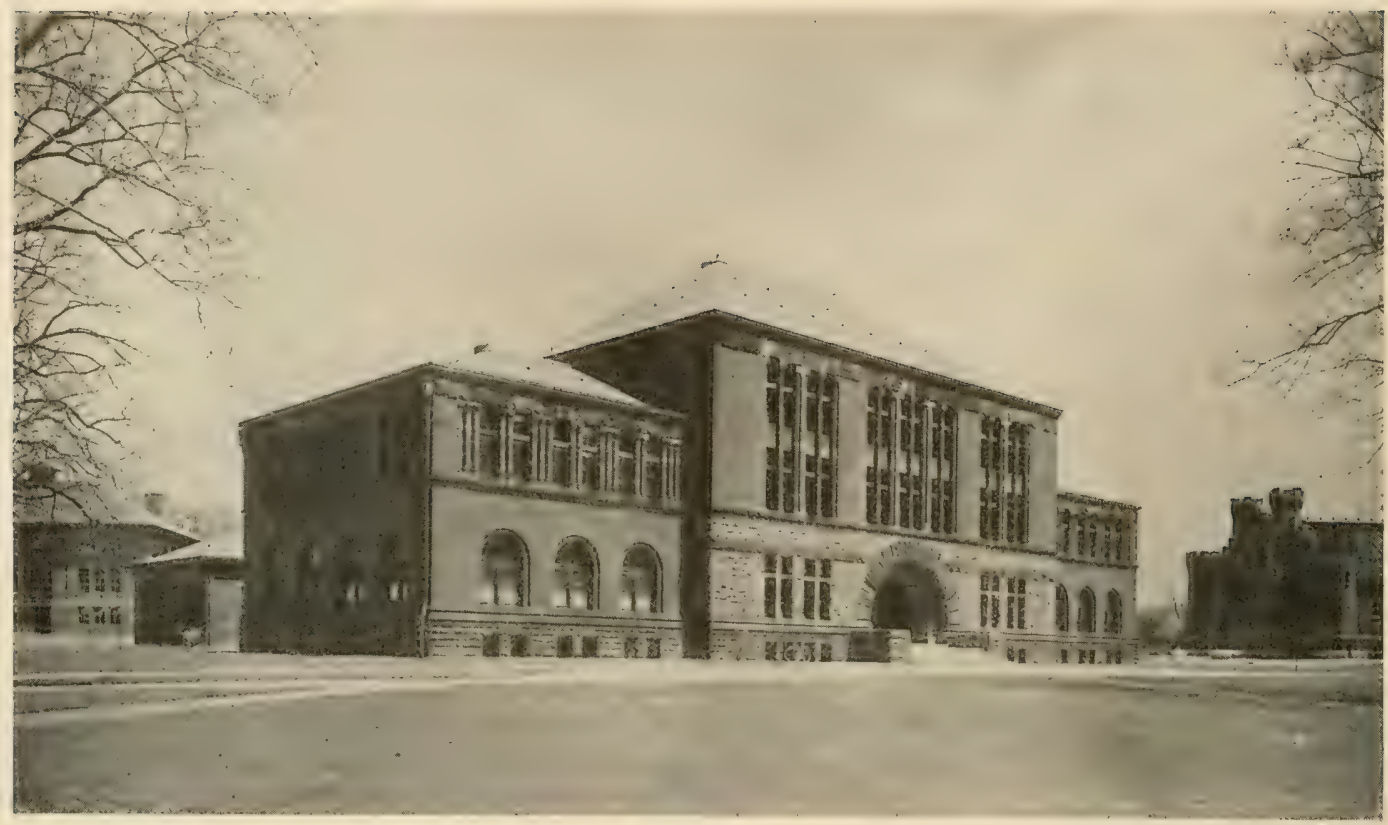

HAYES HALL

DOMESTIC SCIENCE AND INDUSTRIAL ARTS 

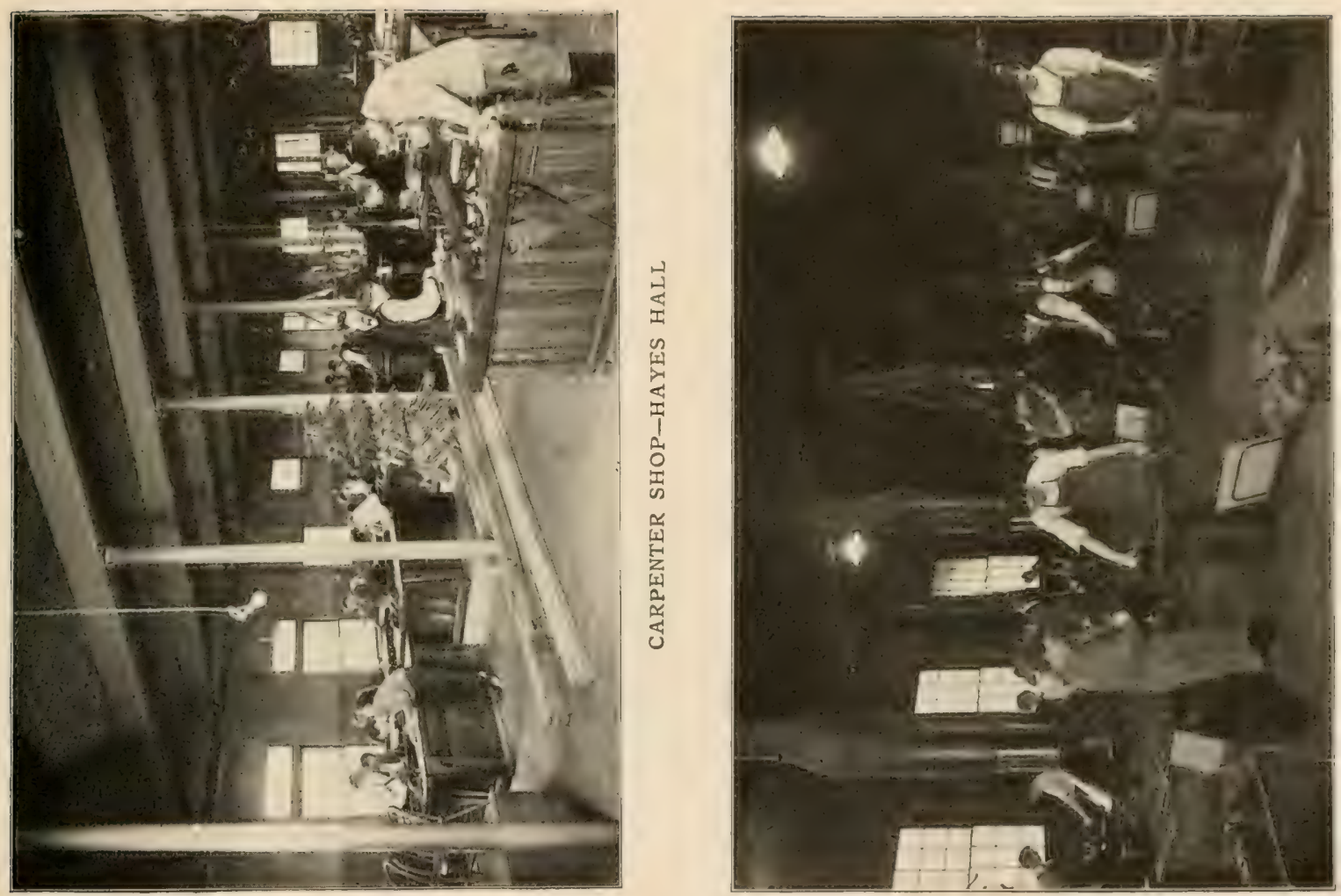


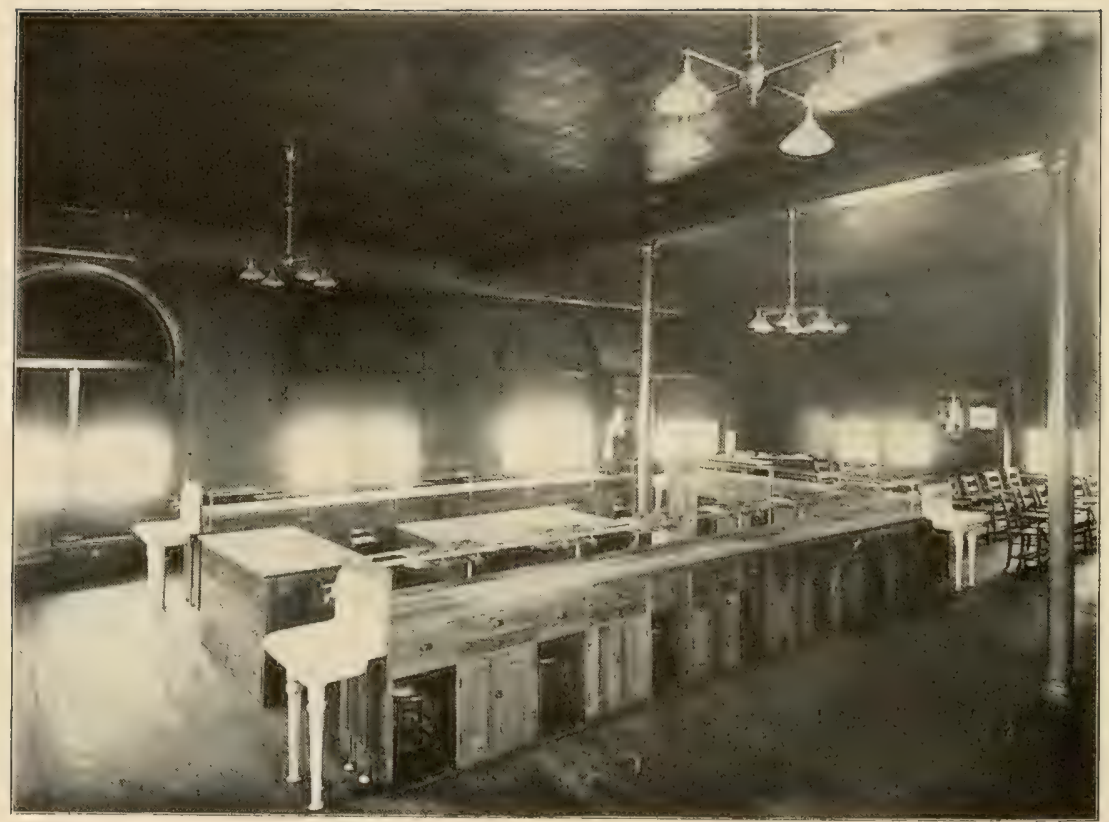

DOMESTIC SCIENCE LABORATORY 


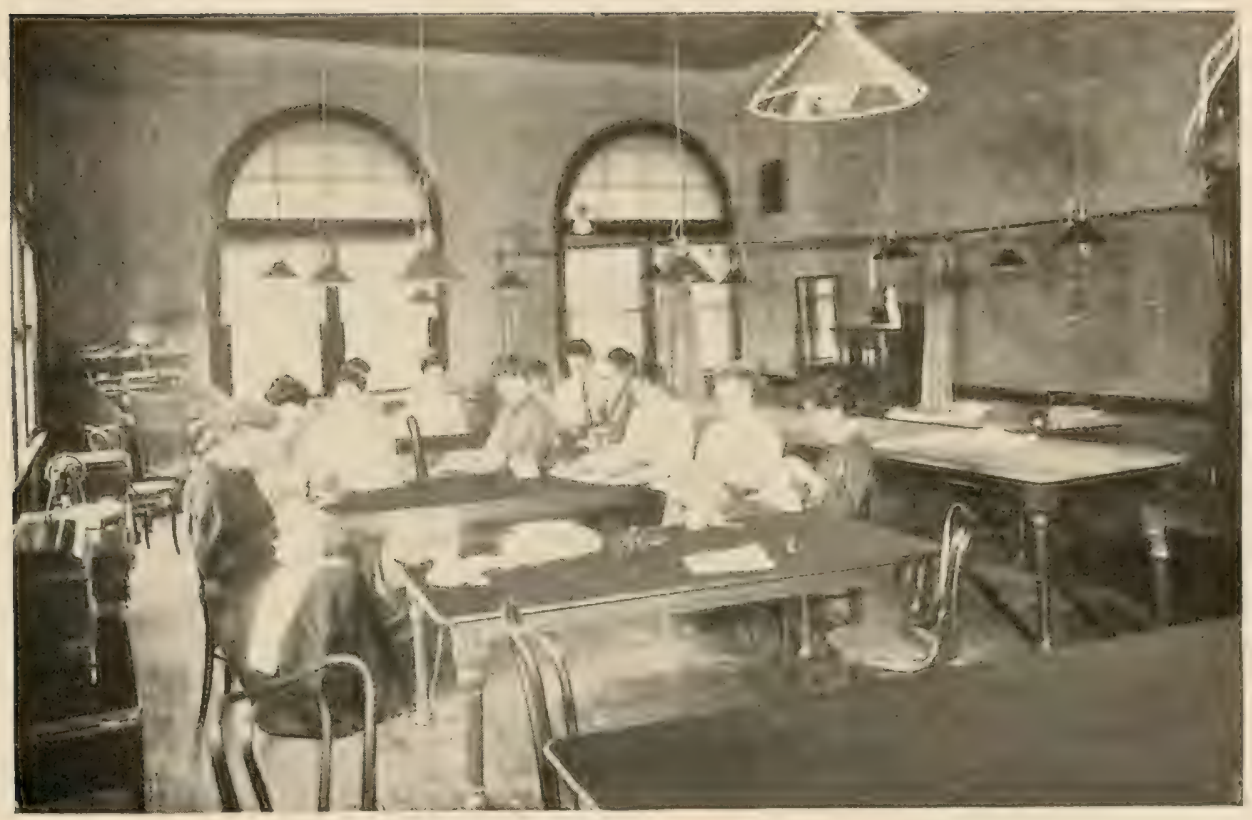

DOMESTIC ART LABORATORY 


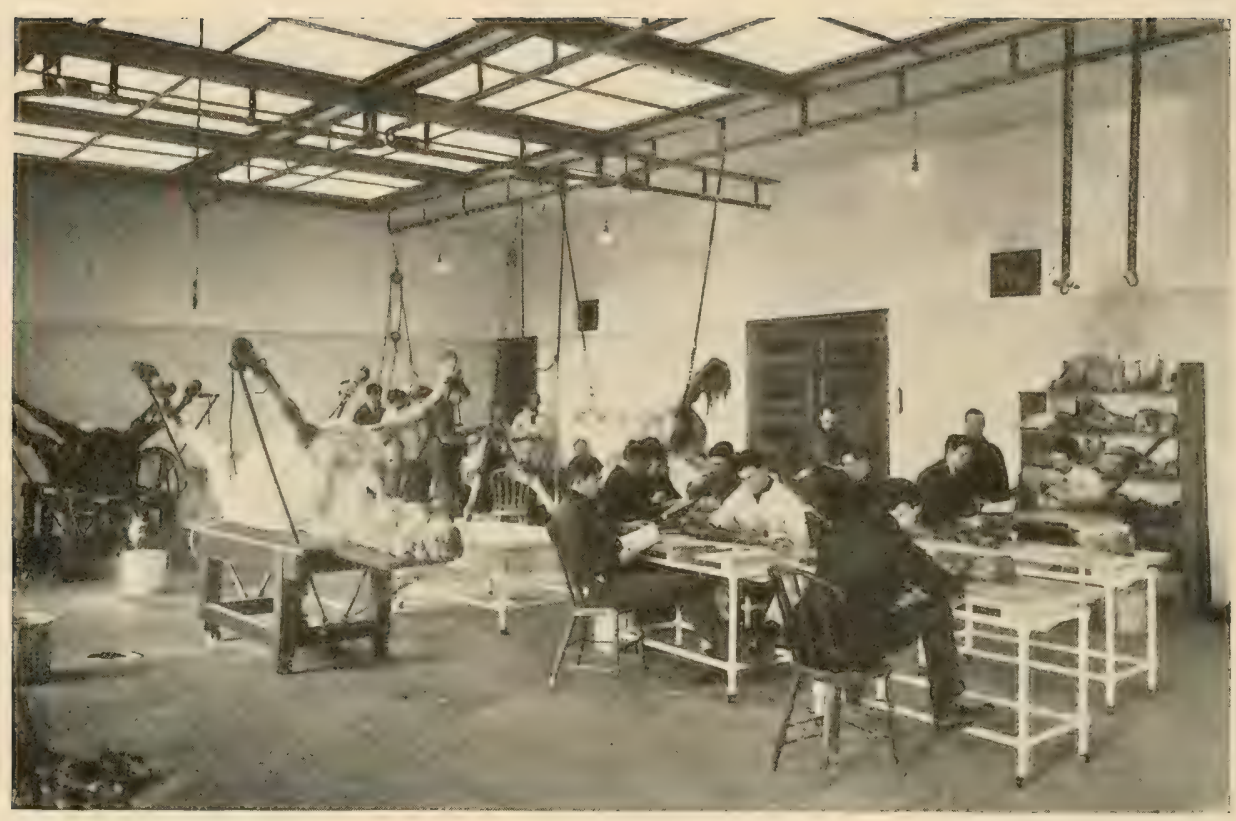

A VETERINARY LABORATORY 


\section{COLLEGE OF AGRICULTURE.}

The College of Agriculture is one of the seven colleges of which the Ohio State University is comprised. Eight distinct courses of study are offered in this College:

1. A four-year course in Agriculture.

2. A four-year course in Horticulture.

3. A four-year course in Fotesury.

4. A four-year course in Domestic Science.

5. A two-year course in Agriculture.

6. A two-year course in Horticulture.

7. A winter course in Dairying.

8. An eight-weel winter course in Agriculture.

For bulletin describing fully these courses address

W. E. MANN, University Editor, Columbus, Ohio. 


\section{LIBRARY OF CONGRESS}

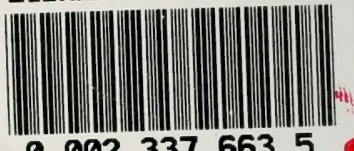

The Ohio State University Bulletin is issued at least: fifteen fimes during the Academic year, monthly in October, November, and June, and bi-weekly in December, Jenuary, February. March: April, and May. 


\section{LIBRARY OF CONGRESS}

|

000233766 35

Hollinger Corp. $\mathrm{pH} 8.5$ 